\title{
Cover components on long-term seasonal sheep grazing treatments in three-tip sagebrush steppe
}

\author{
EDWARD W. BORK, NEIL E. WEST, AND JOHN W. WALKER
}

\begin{abstract}
Authors are former graduate research assistant and professor, Department of Rangeland Resources, Utah State University, Logan, Utah 84322-5230, and former range scientist, USDA-ARS, U.S. Sheep Experiment Station, Dubois, Ida. 83423, current address, Texas Agricultural Experiment Station, 7887 North Highway 87, San Angelo, Tex. 76901. Bork's current address, Department of Agricultural, Food, and Nutritional Science, 410 Agriculture/Forestry Center, University of Alberta, Edmonton, Alberta T6G 2P5, Canada.
\end{abstract}

\begin{abstract}
The effects of fall and spring sheep use on cover components and recovery following a change in seasonality of grazing practices, were studied within long-term grazing treatments of threetip sagebrush (Artemisia tripartita Rydb.) steppe on the U.S. Sheep Experiment Station near Dubois, Ida. Few significant differences existed among treatments within the litter, moss, lichen, and soil components, but several differences in vegetational cover categories occurred. More live shrub and annual grass cover were observed in the long-term (since 1924) and new spring (since 1950) treatments than in the long-term fall (since 1924), new fall (since 1950), old exclosure (since 1940), and new exclosure (since 1950) $(P<0.01)$. More perennial grass and forb cover, and less dead shrub cover existed in fall-grazed treatments $(P<$ 0.01 ). The new fall- grazed treatment previously grazed in the spring failed to reach a more uniform mixture of perennial growth forms after 46 years such as was evident in the long-term fall, which suggests low resilience following spring grazing. The exclosure which was heavily spring and fall-grazed prior to 1950 had even less perennial forb cover than the new fall treatment, indicating that the cessation of sheep grazing did not promote herb recovery any better than continued fall use. The direct impact of sheep herbivory and its indirect effects on the competitive relationships among major plants appear to have affected the cover of sagebrush steppe components at this study site.
\end{abstract}

Key Words: Artemisia tripartita, grazing season, rangeland indicators, resilience

Mueggler (1950) and Laycock (1967), studying a set of paddocks and exclosures established in 1924 at the U.S. Sheep Experiment Station near Dubois, Idaho (Craddock and Forsling 1938), found that sheep grazing during the fall rather than spring on three-tip sagebrush (Artemisia tripartita Rydb.) steppe range-

Funding for this project was provided by the Utah Agricultural Experiment Station, Utah State University, Logan, Utah 84322-4810, and was approved as journal paper no. 4981. Additional support was provided by the U.S. Sheep Experiment Station. The authors thank Scott McKoy and Kevin Price for their assistance during data collection, and Susan Durham for help with the statistical analysis. The authors also thank Jay Anderson, Bill Laycock, and Scott Werner along with 2 anonymous reviewers for their comments on earlier versions of the manuscript.

Manuscript Accepted 5 Jul. 1997.

\section{Resumen}

Fueron estudiados los efectos en los componentes de cobertura y recuperación del uso por las ovejas en otoño y primavera siguiendo un cambio en una temporada de prácticas pastorales. Se estudiaron estos efectos dentro de un periódo de tratamientos de pastoreo de largo-plaza de estepa Artemisia tripartita Rydb. en areas situadas al U.S. Sheep Experimental Station cerca de Dubois, Ida. Existieron pocas diferencias significativas entre los tratamientos dentro del mantillo, muso, liquen, y componentes del suelo. Pero se encontraron varias diferencias en las categorias de cobertura de la vegetación. Se observaron más arbustos vivos y cobertura de pasto annual de tratamientos de largo plazo (desde 1924) y de los nuevos tratamientos de primavera (desde 1950) quen en los tratamientos del largo plazo de otoño (desde 1924), otoño nuevo (desde 1950), exclusiones más viejas (desde 1940), y exclusiones más nuevas (desde (1950) $(p<0.01)$. En los tratamientos de otoño, mas pasto perenne y cobertura de matas y menos cobertura arbusto muerto existieron en los tratamientos en areas de pastoreo en otoño $(P<0.01)$. El tratamiento nuevo de areas pastores en otoño que anteriormente habían sido pastadas en la primavera, falló en alcanzar una mezcla más uniforme de formas de perennes cultivadas después de $\mathbf{4 6}$ años como fue evidente en el otoño de largo-plazo. Estos resultos sugieren la elasticidad mínima siguiendo areas de pastoreo en primavera. La exclusión que estaba muy pastada en primavera y otoño antes de 1950 tuvo menos cobertura de matas que el tratamiento nuevo de otoño. Estos resultos indican que la cesación de pasto de ovejas no adelantó la recuperación de hierbas mejor que el uso continuo de otoño. El impacto directo de ovejas herbívoras y sus efectos directos en las relaciones competidoras entre las plantas principales, aparecieron tener efectos en los componentes de estepa artemisa de cobertura en este investigación.

land, decreases the production of sagebrush and increases that of native perennial herbs. We were interested in whether these differences had persisted until 1995-96 and could be better interpreted under the more contemporary notions of vegetation rcsponse to disturbance, as expressed by the cover of individual rangeland components such as plant growth forms. In this study, data were collected and compared among grazing treatments (paddocks and exclosures) to reveal how resilient various ground cover components are to differences in the seasonality of past sheep use. On rangelands, resilience is the speed at which a plant 
community recovers from a disturbed condition towards its original state (Archer and Smeins 1991). Resilience is determined by the original community as well as by the type and magnitude of disturbance (e.g., Belnap et al. 1994). A better understanding of resilience would help managers identify time frames during which management changes are likely to alter the condition of rangelands. The objectives of this investigation were (1) to assess the vegetation differences among various seasonal grazing treatments within the study area, and (2) to examine the resilience (i.e., recovery) of three-tip sagebrush steppe vegetation previuusly spring and fall-grazed (prior to 1950), and currently ungrazed or fall-grazed by sheep.

\section{Study Site}

Research was conducted during 1995 and 1996 at the U.S. Sheep Experiment Station, $10 \mathrm{~km}$ north of Dubois, Ida. ( $44^{\circ} 14^{\prime} 44^{\prime \prime}$ N. Latitude, $112^{\circ} 12^{\prime} 47^{\prime \prime}$ W. Longitude). Station headquarters is situated at $1,650 \mathrm{~m}$ elevation in the northeastern portion of the sagebrush steppe ecosystem type (West 1983). Vegetation is dominated by three-tip sagebrush, bluebunch wheatgrass (Pseudoroegnaria spicata [Pursh] A Löve), and arrowleaf balsamroot (Balsamorhiza saggitata [Pursh] Nutt.) (Laycock 1963, preferred latin names of Kartesz 1994). Three-tip sagebrush is found on approximately 3.4 million ha of the Northern Rocky Mountains and Great Basin of the U.S., typically at locations elevationally above Wyoming big sagebrush (Artemisia tridentata Nutt. ssp. wyomingensis) but below mountain big sagebrush (Artemisia tridentata Nutt. ssp. vaseyana) (Blaisdell et al. 1982).

Climate of the study area is semiarid with cold winters and warm summers. Annual precipitation has averaged $301 \mathrm{~mm}$ over the past 71 years, including about $700 \mathrm{~mm}$ of snow. Average annual temperature is $6.1^{\circ} \mathrm{C}$ (Anon. 1993) with extreme temperatures ranging from $37.8^{\circ} \mathrm{C}$ in summer to $-31.7^{\circ} \mathrm{C}$ in winter. Average frost-free period is 120 days (Laycock 1963).

Soils in the area are derived from wind-blown loess, residuum, or alluvium on slopes ranging from $0-12 \%$, and are dominated by fine-loamy, mixed, frigid Calcic Argixerolls (Natural Resources Conservation Scrvice, 1995). Soil characteristics are variable across the landscape because of the varying thickness of parent material overlying the basalt bedrock. The complexity of soil depths makes landscape stratification difficult. A related investigation of the spatial patterns of parent material depth (Bork et al. in press) showed that soil depths among the treatments appear to be, on the whole, very similar.

The 6 grazing treatments, between 4 and 12.5 ha in sizc, were established between 1924 and 1950. They included 2 long-term spring-grazed, 2 fall-grazed, and 2 exclosure treatments (Fig. 1). These treatments were initially used to differentiate between the impact of annual sheep grazing only during the fall (November and December) (paddocks 1, 2, and 3) versus spring and fall (May) (paddocks 4, 5, and 6) (Table 1). Paddock 3 was exclosed from sheep in 1940 following 17 years of fall-only grazing. The subsequent findings of this first phase of the study (e.g., Craddock and Forsling 1938, Mueggler 1950) were used to derive guidelines for managing sheep use of these rangelands (Pechanec and Stewart 1949).

In 1950, another exclosure was constructed within the former spring treatment (paddock 6). Also at this time, the 2 original fall and spring treatments were each subdivided into 2 new paddocks. While 2 of the paddocks continued to be fall and spring-grazed as before, the remaining pair of paddocks were switched to the alternate season of use. The new exclosure and new fall-grazed treatment were subsequently used to evaluate three-tip sagebrush steppe recovery following a change in the seasonality of sheep use.

Although the long-term grazing history of each treatment differs (e.g., see stocking rates; Table 1), the seasonality of use since 1950 has been consistent within paddocks. The longevity of the treatments on this particular site (ca. 72 years) offers a unique opportunity to document the long-term response of these rangelands following the changes in seasonal grazing practices in 1950. To facilitate the comparison of cover components among treatments, paddocks were not grazed by livestock in 1995 or 1996.

\section{Methods}

\section{Vegetation Sampling}

Previous studies have collected primarily density, frequency, and production data from the area. In this study, cover data were collected during 1995 and 1996 from plots located within all 6 treatment paddocks and exclosures (Fig. 1), using a modified point sampling method (Floyd and Anderson 1982, 1987). Cover was chosen because this variable best relates the abundance of

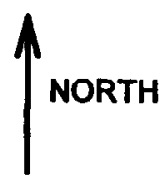

New Exclosure (est. 1950)

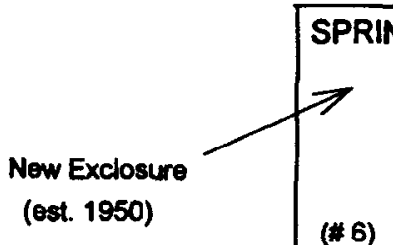

(\#6)
SPRING \& FALL - GRAZED from 1924 to 1950

Fall - Grazed

after 1950

(\# 5)

(*4)

Continued Spring

Use after 1950

FALL - GRAZED from t924 to 1950

Old Exclosure

(est. 1940)

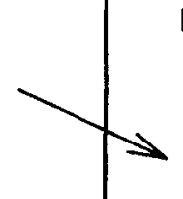

(* 3)
Spring - Grazed

after 1950
Continued Fall

Use after 1950

(*2)

\section{Main Road}

Fig. 1. Layout of the seasonal grazing paddocks at the USDA/ARS Sheep Experiment Station, Dubois, Ida., summer 1995 (adapted from Laycock 1967). 
Table 1. Summary of the historical timing of grazing and mean stocking rates* on the long-term seasonal grazing trial at the U.S. Sheep Experiment Station, near Dubois, Ida. Seasonal grazing treatments are spring-grazed (Spring), fall-grazed (Fall), spring and fall-grazed (Sp \& Fa), and exclosed (Excl). See Fig. 1 for paddock locations.

\begin{tabular}{|c|c|c|c|c|c|c|c|c|c|}
\hline \multirow{2}{*}{$\begin{array}{l}\text { Paddock\#: } \\
\text { Timing of Grazin }\end{array}$} & \multirow[t]{2}{*}{1} & \multirow[t]{2}{*}{2} & \multirow[t]{2}{*}{3} & \multicolumn{2}{|c|}{4} & \multicolumn{2}{|c|}{5} & \multicolumn{2}{|c|}{6} \\
\hline & & & & \multirow{2}{*}{\multicolumn{2}{|c|}{$\mathrm{Sp} \& \mathrm{Fa}$}} & & & & \\
\hline $1923-1940$ & Fall & Fall & Fall & & & \multicolumn{2}{|c|}{$\mathrm{Sp} \& \mathrm{Fa}$} & \multicolumn{2}{|c|}{$\mathrm{Sp} \& \mathrm{Fa}$} \\
\hline 1941-1949 & Fall & Fall & Excl. & \multicolumn{2}{|c|}{ Sp \& Fa } & \multicolumn{2}{|c|}{$\mathrm{Sp} \& \mathrm{Fa}$} & \multicolumn{2}{|c|}{ Sp \& Fa } \\
\hline \multicolumn{10}{|c|}{ Stocking Rates: } \\
\hline \multirow[t]{2}{*}{$1923-1929$} & 61.8 & 61.8 & 61.8 & 34 & $S$ & 34 & $S p$ & 34 & $\mathrm{Sp}$ \\
\hline & & & & 13 & $\mathbf{F a}$ & 13 & $\mathbf{F a}$ & 13 & $\mathrm{Fa}$ \\
\hline \multirow[t]{2}{*}{$1936-1940$} & 38.2 & 38.2 & 38.2 & 9.6 & $S p$ & 9.6 & $\mathrm{Sp}$ & 9.6 & Sp \\
\hline & & & & 8 & $\mathrm{Fa}$ & 8 & $\mathrm{Fa}$ & 8 & $\mathrm{Fa}$ \\
\hline \multirow[t]{2}{*}{$1941-1949$} & 30.6 & 30.6 & 0 & 14 & Sp & 14 & $\mathrm{Sp}$ & 14 & Sp \\
\hline & & & & 11 & $\mathbf{F a}$ & 11 & $\mathrm{Fa}$ & 11 & $\mathrm{Fa}$ \\
\hline $1950-1996$ & 60 & 40 & 0 & & 40 & & 60 & & \\
\hline
\end{tabular}

*Approximate average stocking rates are in Sheep-Days per Acre, from Mueggler (1950) and Laycock 1967).

plant growth forms to spectrometer data, which were collected in a related investigation (Bork, unpubl. data). Cover data were collected during peak green plant growth between 20 and 24 June 1995 , and 2 and 16 June 1996 . Eight randomly placed, $1.75 \mathrm{~m}^{2}$ plots (i.e., sampling units) were sampled within each paddock in 1995. This number was increased to 30 in 1996 to improve the statistical power of the comparison among treatments.

Each plot was circular to accommodate the footprint of a spectrometer used in the related studies (Bork, unpubl, data). Based on the results of a pilot study, a minimum of 150 points per plot were necessary to stabilize cover component values. As a result, each plot was sampled using 164 systematic points located 10.5 $\mathrm{cm}$ apart. Two sets of cross wires, $20 \mathrm{~cm}$ apart vertically, were used to minimize parallax when reading each point (Iloyd and Anderson 1982, 1987).

Features directly below each point (i.e., exposed rock, bare soil, moss, lichen, litter, dead shrub, or live vegetation by species) was recorded. While herbaceous standing dead matter was treated as litter because it usually becomes flattened by snow packs during the next winter, standing dead shrub was recorded separately as an indicator of shrub mortality. In addition to the cover data, repeat density data for arrowleaf balsamroot were collected from a series (the number ranged from 15 to 25 per treatment) of permanent circular $9.3 \mathrm{~m}^{2}\left(100 \mathrm{ft}^{2}\right)$ plots established in the original fall and the spring and fall paddocks prior to 1950 , and in the remaining treatments after that time. Although sagebrush stems were counted in earlier studies (e.g., Laycock 1967), the imprecise definition of an individual 'plant' made temporal comparisons unreliable.

\section{Data Analysis}

All point data were summarized for each plot into 6 vegetational and 5 soil surface-based components for statistical analysis among grazing treatments. Vegetation components included total live vegetation, perennial and annual grass, perennial and annual forb, live shrub, and standing dead shrub. Growth forms were examined instead of species because they represent the primary source of historical change within the study area (Mueggler 1950, Laycock 1967), are practical indicators of range condition (Friedel et al. 1988), and statistically, yield more-reliable data than individual species. Soil surface-based components were considered because of their strung relationship to current range condition theory (National Research Council 1994), and included the cover of litter, lichen, moss, bare soil, and rock.

Cover data were analyzed using a two-way factorial analysis of variance. For each of the 11 cover components, 6 pre-planned, single degree of freedom contrasts were evaluated among the treatments. Time of sampling (i.e., year) and treatment by time interactions were also examined to determine the reliability of any significant main treatment effects found. Because treatments were unreplicated, the results will be treated as a case study, with statistical inferences applying only to the study area in order to avoid misinterpretation (Hurlbert 1984).

Of each set of 6 contrasts, 3 were tested for differences among the 2 spring-grazed, 2 fall-grazed, and 2 exclosed (ungrazed) treatment paddocks. These pooled comparisons among the 3 primary treatments determined the general effects of seasonal sheep herbivory (i.e., timing) since 1950. The 3 other contrasts tested for differences between the 2 'replicates' within each primary type of treatment. Cover component differences in these pairwise comparisons showed the residual effect of seasonal grazing incurred prior to 1950 , by indicating each treatment's relative response since that time. Different significance levels were used for the pooled $(\mathbb{N}=$ $76 ; \mathrm{P}<0.01)$ and pairwise $(\mathrm{N}=38 ; \mathrm{P}<0.05)$ contrasts.

Mean balsamroot densities were compared among the grazing treatments for the years 1949,1964 , and 1996, with the latter facilitating comparison to the cover data. Statistical analysis was impossible because individual plot data were unavailable for the first 2 sampling dates.

\section{Results}

Significant differences were found within most of the 11 rangeland cover components examined for both the pooled and pairwise contrasts (Table 2, Fig. 2). However, fewer differences were found for the soil surface-based components. Although no significant differences were apparent for total live vegetation cover, all of the other vegetational components (i.e., growth forms) did show differences among treatments (Table 2, Fig. 2). The time 
Table 2. Mean cover values (for the period 1995 to 1996) and standard errors (SE) for growth forms and soil surface-based components within the seasonal fall, spring, and exclosed treatments $\left(N=78\right.$ treatment $\left.^{-1}\right)$.

\begin{tabular}{|c|c|c|c|c|c|c|c|c|}
\hline \multirow[t]{2}{*}{ Pooled Treatment:: } & \multicolumn{3}{|c|}{ Fall-Grazed } & \multicolumn{2}{|c|}{ Spring-Grazed } & \multicolumn{3}{|c|}{ Exclosed } \\
\hline & Mean & & SE & Mean & SE & Mean & & SE \\
\hline Vascular Vegetation: & $\overline{(\%)}$ & & & $(\%)$ & & (\%) & & \\
\hline Total Live Vegetation & 49.3 & $a^{1}$ & 1.44 & 50.1 & a 1.19 & 46.2 & $\mathrm{a}$ & 1.32 \\
\hline Standing Dead Shrub & 5.1 & $\mathrm{~b}$ & 0.53 & 9.6 & a 0.68 & 8.0 & $\mathbf{a}$ & 0.60 \\
\hline Live Herb & 30.3 & a & 1.27 & 22.9 & b 0.92 & 24.8 & $\mathbf{b}$ & 0.98 \\
\hline Live Grass & 17.0 & a & 0.85 & 14.6 & a $\quad 0.85$ & 15.7 & $\mathrm{a}$ & 0.74 \\
\hline Annual Grass & 0.8 & $\mathrm{~b}$ & 0.21 & 5.1 & a 0.84 & 1.4 & b & 0.39 \\
\hline Annual Forb & 3.8 & $\mathrm{a}$ & 0.58 & 4.9 & a 0.50 & 1.8 & $\mathrm{~b}$ & 0.32 \\
\hline Perennial Forb & 8.5 & $\mathbf{a}$ & 1.04 & 2.3 & b $\quad 0.26$ & 8.4 & $\mathbf{a}$ & 0.82 \\
\hline \multicolumn{9}{|c|}{ Soil Surface-Based Components: } \\
\hline Litter & 15.8 & $\mathbf{a}$ & 0.91 & 18.4 & a $\quad 0.74$ & 17.4 & $\mathrm{a}$ & 0.79 \\
\hline Moss $^{2}$ & 1.3 & $b^{*}$ & 0.22 & 1.7 & b 0.26 & 4.2 & $a^{*}$ & 0.40 \\
\hline Lichen & 5.8 & $\mathbf{a}$ & 1.30 & 3.3 & a $\quad 0.92$ & 3.9 & $\mathrm{a}$ & 0.83 \\
\hline
\end{tabular}

Within components, treatment means with the same letter were not significantly different $(\mathrm{P}<0.01)$

${ }^{2}$ Within components, treatment means with an '*' were significantly different when tested against the year by treatment interaction (P<0.01).

(i.e., year) of data collection was not important in any comparisons, although a few significant treatment by time interactions did occur.

Totals of 58 and 57 vascular plant species were documented in 1995 and 1996, respectively. The canopy cover of all species having at least $0.5 \%$ cover within a treatment are listed in Table 3 for the 6 individual paddocks and 3 primary treatments, led by the predominant shrub, three-tip sagebrush. The most common annual forb species included pepperweed (Lepidium montanum Nutt.) and blue-eyed Mary (Collinsia parviflora Lindl.), while

Table 3. Mean canopy cover (for the period 1995 to 1996) by major ( $>0.5 \%$ cover) plant species within the 6 seasonal grazing treatments at the USSES, Dubois, Ida. Latin names are according to Kartesz (1994). Pooled means are for the fall-grazed (Fall), spring-grazed (Spring), and exclosed (Excl) treatments. Individual comparisons are for the long-term fall grazed (LTF), spring to fall in 1950 (Sp-Fa), fall to spring in 1950 (Fa-Sp), fall to spring in 1950 (Fa-Sp), long-term spring grazed (LTS), the old exclosure (OEx, ereated in 1940), and the new exclosure (NEx, created in 1950).

\begin{tabular}{|c|c|c|c|c|c|c|c|c|c|}
\hline & \multicolumn{2}{|c|}{ Pooled Treatment ${ }^{1}$} & \multicolumn{7}{|c|}{ Individual Paddocks } \\
\hline & Fall & Spring & Excl & LTF & $\mathrm{Sp}-\mathrm{Fa}$ & LTS & $\mathrm{Fa}-\mathrm{Sp}$ & OEx & NEx \\
\hline Shrubs & $-\ldots$ & $-\ldots . .-\ldots$ & $-\ldots$ & $\ldots$ & $-(\%)-$ & $--{ }_{-1}$ & $\ldots \ldots$ & $-\cdots-$ & $\ldots \ldots$ \\
\hline Artemisia tripartita & 13.9 & 23.5 & 15.1 & 13.4 & 14.8 & 21.3 & 25.7 & 14.8 & 15.3 \\
\hline Chrysothamnus viscidiflorus & 1.5 & 0.9 & 0.8 & 1.2 & 1.8 & 1.3 & 0.4 & 0.5 & 1.0 \\
\hline Eriogonum heracleoides & 0.2 & $\mathrm{~T}^{2}$ & 0.5 & 0.3 & 0.1 & $\mathbf{T}$ & 0 & 0.7 & 0.3 \\
\hline Leptodactylon pungens & 1.1 & 1.3 & 0.7 & 1.4 & 0.8 & 1.6 & 1.0 & 0.4 & 1.0 \\
\hline Purshia tridentata & 1.1 & 1.2 & 2.8 & 0.7 & 1.5 & 1.3 & 1.1 & 2.3 & 3.2 \\
\hline Tetradymia canescens & 0.7 & 0.1 & 1.2 & 0.5 & 1.0 & $\mathrm{~T}$ & 0.2 & 1.3 & 1.0 \\
\hline Other Minor Shrubs & 0.5 & 0.2 & 0.3 & $\mathrm{~T}$ & 0.5 & 0.1 & 0.3 & 0.5 & 0.4 \\
\hline \multicolumn{10}{|l|}{ Annual Forbs } \\
\hline Collinsia parviflora & 0.8 & 0.7 & 0.4 & $\mathrm{~T}$ & 0.7 & 0.6 & 0.7 & 0.4 & 0.4 \\
\hline Lepidium montanum & 2.7 & 3.4 & 0.8 & 2.8 & 2.6 & 2.7 & 4.3 & 1.5 & 0.1 \\
\hline Other Minor Annual Forbs & 0.3 & 0.8 & 0.6 & 0.5 & 0.9 & 0.9 & 0.7 & 0.5 & 0.7 \\
\hline \multicolumn{10}{|l|}{ Perennial Forbs } \\
\hline Arnica fulgens & 0.5 & $\mathrm{~T}$ & 0.1 & 0 & 0.9 & $T$ & $\mathrm{~T}$ & 0 & 0.3 \\
\hline Balsamorhiza sagittata & 4.8 & $\mathrm{~T}$ & 5.3 & 8.0 & 1.7 & $\mathrm{~T}$ & $\mathrm{~T}$ & 8.8 & 1.8 \\
\hline Crepis acuminata & 0.8 & 0.1 & 0.6 & 0.6 & 1.0 & 0.1 & 0.1 & 0.5 & 0.6 \\
\hline Erigeron caespitosus & 0.5 & 0.3 & 0.1 & 0.4 & 0.5 & 0.3 & 0.3 & 0.1 & 0.1 \\
\hline Lomatium dissectum & 0.4 & 0.1 & 0.1 & 0.2 & 0.5 & 0.1 & 0.1 & 0.1 & 0.1 \\
\hline Other Perennial Forbs & 1.5 & 1.7 & 2.2 & 2.1 & 3.1 & 1.7 & 1.7 & 1.4 & 3.0 \\
\hline \multicolumn{10}{|l|}{ Annual Grass } \\
\hline Bromus tectorum & 0.8 & 5.1 & 1.4 & 0.5 & 1.1 & 6.6 & 3.9 & 1.7 & 1.1 \\
\hline Other Annual Grasses & $T$ & 0 & 0 & 0 & $\mathrm{~T}$ & 0 & 0 & 0 & 0 \\
\hline \multicolumn{10}{|l|}{ Perennial Grass } \\
\hline Elymus lanceolatus & 0.4 & 0.3 & 0.4 & 0.2 & 0.5 & 0.2 & 0.5 & 0.3 & 0.5 \\
\hline Koeleria macrantha & 0.9 & 0.2 & 0.5 & 1.0 & 0.8 & 0.2 & 0.2 & 0.4 & 0.6 \\
\hline Poa secunda & 5.9 & 5.5 & 3.4 & 6.0 & 5.8 & 7.6 & 3.4 & 2.8 & 4.1 \\
\hline Oryzopis hymenoides & 0.3 & 0.5 & 0.4 & 0.3 & 0.2 & 0.6 & 0.3 & 0.6 & 0.2 \\
\hline Pseudoroegnaria spicata & 8.4 & 4.0 & 8.4 & 7.7 & 9.1 & 4.7 & 3.3 & 7.5 & 9.4 \\
\hline Other Perennial Grasses & 0.3 & 0.1 & 0.3 & 0.5 & 0.3 & $\mathbf{T}$ & 0.2 & $\mathrm{~T}$ & 0.1 \\
\hline
\end{tabular}

Denotes mean cover values from cross-over 'replicate' paddocks.

${ }^{2}$ Denotes trace amounts, less than $0.05 \%$ by cover. 

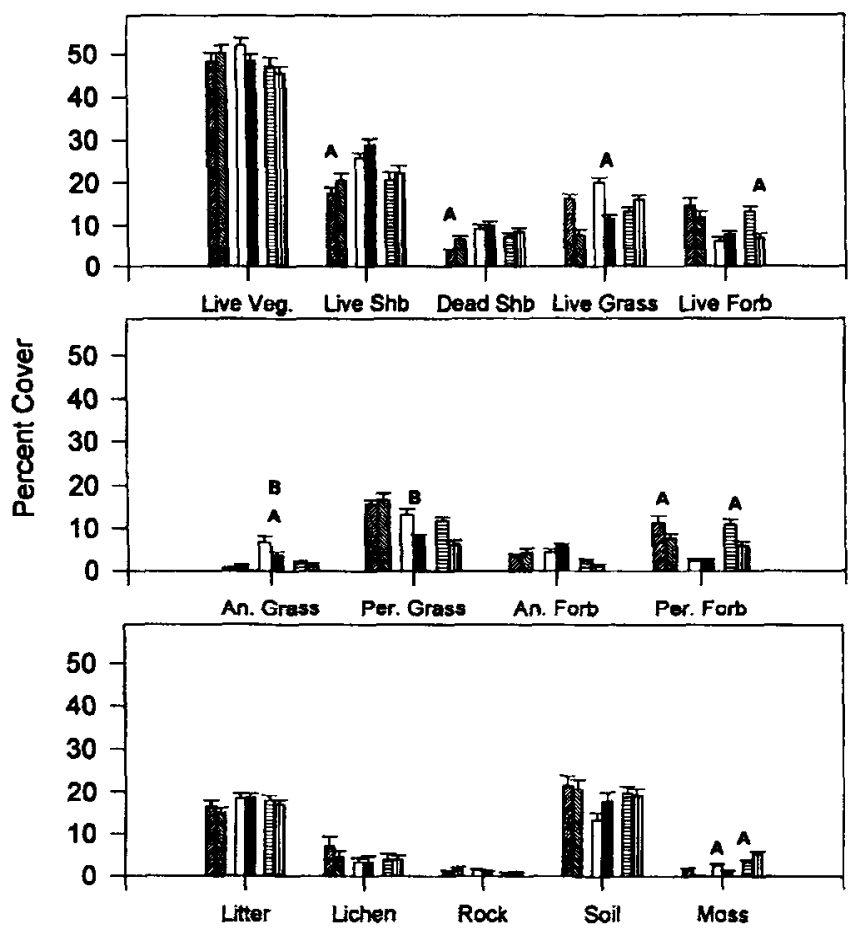

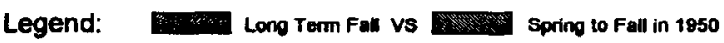

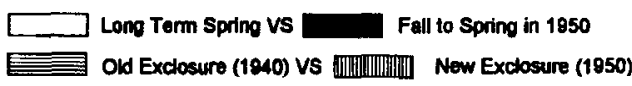

Fig. 2. Mean ground cover and standard errors for the comparisons between 'replicate' graxing treatments for all components. Significant contrasts are against treatment $(A)$ and treatment by time (B), respectively (minimum $P<0.05$ ).

balsamroot, arnica (Arnica fulgens Pursh), hawksbeard (Crepis acuminata Nutt.), and groundsel (Senecio integerrimus Nutt.) were common perennials (Table 3). Cheatgrass (Bromus tectorum L.) was the primary annual grass. Perennial grass cover was dominated by bluebunch wheatgrass, with lesser amounts of Sandberg bluegrass (Poa secunda J. Presl), needle and thread (Stipa comata Trin. \& Rupr.), Indian ricegrass (Oryzopsis hymenoides [Roemer \& J.A. Schultes] Ricker ex. Piper), and prairie junegrass (Koeleria macrantha [Ledeb.] J.A. Schultes) ('Table 3).

\section{Post-1950 (Pooled) Comparisons}

Live shrub cover was significantly greater within the spring treatment than within the fall and exclosed treatments (Table 2). However, less standing dead shrub cover occurred in the fall compared to the other 2 pooled treatments. Three-tip sagebrush accounted for most of the shrub cover, with bitterbrush and horsebrush subdominants (Table 3 ).

Live herb and forb cover were greater on the fall treatment than on either the spring or exclosed areas (Table 2). However, grass cover did not differ among any of the 3 pooled treatments. Further differences were apparent when annual and perennial grasses were examined separately (Table 2). Annual grass cover was greater within the spring treatment than in the fall and exclosed treatments (Table 2). In contrast, perennial grass cover within the spring treatment was significantly lower than in the other 2 (Table 2).

Annual and perennial forbs exhibited a similar pattern to grass cover, with less perennial forb cover in the spring treatment relative to the other 2 pooled treatments (Table 2). However, annual forb cover was lower in the exclosures compared to both the spring and fall-grazed treatments.

In general, few differences occurred within the soil surfacebased components (Table 2). However, the fall treatment had significantly more bare soil than the spring, and exclosures had greater moss cover than the spring treatment. More moss cover occurred in the exclosures than in the fall treatment, but this comparison had a significant treatment by time interaction as well.

Moss cover in the fall treatments remained relatively stable from 1995 (1.4\%) to 1996 (1.3\%), but increased in the exclosures from $2.1 \%$ to $4.7 \%$ over the same period. Because moss cover could be expected to respond relatively slowly in this semiarid rangeland (West 1990), the observed interaction may be of little biological significance, and could be an artifact of the difference in sample sizes between years (8 vs 30 plots per paddock in 1995 and 1996, respectively).

Comparative balsamroot densities among the pooled grazing treatments (Table 4) generally appeared to follow a similar trend to the perennial forb cover data. The greatest densities were found in the fall-grazed paddocks and exclosures (Table 4). Balsamroot densities in each of the 3 pooled treatments have generally continued to decline from 1949 through 1996.

Table 4. Mean balsamroot density for 1949, 1964, and 1996 for individual and pooled paddocks.

\begin{tabular}{lccc}
\hline & \multicolumn{3}{c}{ Year (No. of plants 9.3 $\left.\mathrm{m}^{-2}\left[100 \mathrm{ft}^{-2}\right]\right)$} \\
\hline Paddock & 1949 & 1964 & 1996 \\
Long-Term Fall & 20.8 & 14.5 & 9.1 \\
Spring to Fall in 1950 & $\mathrm{N} / \mathrm{A}^{1}$ & 0.7 & 1.1 \\
Pooled Fall & 20.8 & 7.6 & 5.1 \\
Long-Term Spring & 0.6 & 0.2 & 0.1 \\
Fall to Spring in 1950 & N/A & 5.8 & 0 \\
Pooled Spring & 0.6 & 3 & 0.2 \\
Old Exclosure & N/A & 13.1 & 8.1 \\
New Exclosure & N/A & 1.5 & 2.3 \\
Pooled Exclosures & N/A & 9.3 & 5.4 \\
\hline
\end{tabular}

${ }^{1}$ In 1949, only the long-tern paddocks were in existence.

\section{Pre-1950 (Crossed-Over) Comparisons}

Comparisons between pairwise treatment 'replicates' indicated less live and dead shrub cover occurred within the long-term fall paddock (i.e., since 1923) than in the paddock switched to fall only-grazing in 1950 (Fig. 2). The long-term spring paddock had more live grass cover than the new spring only paddock, and live forb cover was greater in the old exclosure relative to the new one (Fig. 2).

Both annual and perennial grass cover were significantly different between the 2 spring treatments in a treatment by time interaction (Fig. 2). Annual grass in the original spring treatment declined from $13.0 \%$ to $4.9 \%$ from 1995 to 1996 , but remained relatively constant at $3.5 \%$ in the new spring-grazed paddock over both years, thereby supporting the main treatment effect. The lack of a main time effect indicates the interaction is proba- 
bly due to the unequal sample sizes within years. Perennial grass cover also had a significant treatment by time interaction (Fig. 2), as it increased from $6.9 \%$ in 1995 to $15.1 \%$ in 1996 on the longterm spring paddock, but declined from $8.5 \%$ to $7.8 \%$ on the new spring-grazed paddock. The old (established in 1940) exclosure had more perennial forb cover than the new (established in 1950) exclosure (Fig. 2). Perennial forb cover was also greater in the long-term fall treatment than in the new fall.

Pairwise comparisons within the soil surface-based components showed few significant differences (Fig. 2). The long-term spring paddock and new exclosure had more moss cover compared to the new spring paddock and old exclosure, respectively (Fig. 2).

Differences in balsamroot densities among paddocks grazed similarly since 1950 (Table 4) closely paralleled the forb cover data. For example, the spring to fall paddock continues to have fewer balsamroot plants than the long-term fall, while the old exclosure has a greater number of balsamroot plants than the new exclosure. In 1964, balsamroot density in the spring to fall paddock was $4 \%$ of its density in the long-term fall. By 1996, balsamroot density in the spring to fall had increased to $12 \%$ of that in the long-term fall paddock. Similarly, balsamroot density increased in the new exclosure from 11 to $28 \%$ of the old exclosure over this period. In contrast, the new spring-grazed paddock, which still had moderate balsamroot numbers in 1964, appears to have lost most of this forb, making it similar to the long-term spring paddock in 1996.

\section{Discussion}

Although total live vegetation cover was similar among the grazing treatments, the cover of growth forms (e.g., forb, grass, and shrub) varied. This suggests that growth forms, rather than total cover, are more sensitive to the past seasonality of sheep grazing in this area. The data also show that although vegetational recovery may be continuing on the areas spring-grazed prior to 1950, residual effects from this period remain evident on both the fall-grazed and ungrazed areas. These differences may indicate that the resilience of this semiarid sagebrush steppe rangeland to spring sheep grazing is quite low, especially the relative abundance (or balance) of growth forms among treatments. It may also indicate that the vegetation in these paddocks has changed to a new steady state (Laycock 1991), with hysteresis resulting in recovery to a new vegetational endpoint. The fact that recovery appears to be continuing, however, albeit slowly, may also suggest that the vegetational changes within the grazing treatments are reversible over the long-term.

Slow recovery of vegetation on this rangeland may also be partly due to the semi-arid moisture regime and poorer opportunities for growth compared to more mesic rangelands. Examination of the yearly (September to August) prccipitation totals since 1925 for the Sheep Station headquarters (data not shown) indicated that fluctuations were commonplace. The 1994-1995 water year was the wettest ever recorded at the Sheep Station (608 mm; $202 \%$ of average). While this may account for the few significant treatment by timc interactions observed within the data, the limited number of significant interactions suggests that the vegetational components within the study area were quite stable despite variation in precipitation. Fortunately, the largest proportion of the study data (180 of 228 plots) were collected in 1996, following a normal precipitation year (e.g., $291 \mathrm{~mm}$; 97\% of average).
The lower live shrub cover found in the fall treatment may reflect the reduced longevity of the predominant shrub, three-tip sagebrush, under this grazing regime (West et al. 1979). Two specific mechanisms may further explain the reduction in shrub cover. Preferential use of shrubs by sheep during the fall was thought to be the mechanism responsible (Mueggler, 1950, Laycock 1967), particularly because three-tip sagebrush is moderately susceptible to defoliation during the fall and winter (Wright 1970). This process would be exacerbated by the lack of available herbs during November and December (i.e., due to senescence and snow cover). However, direct use fails to account for the unexpectedly similar low levels of live shrub cover between the fall and exclosed (ungrazed by sheep) treatments.

Several alternative mechanisms may account for the exclosures containing less live shrub cover relative to the spring treatment. For instance, other disturbances may be occurring within the exclosures to reduce shrubs (e.g., insects and disease). Another possibility is that the relatively lower shrub cover in the fall treatment (versus the spring) may have resulted from the combined effect of direct shrub defoliation by sheep within this area, and the concomitant removal of herbs from spring grazing. The latter may reduce competition with the shrubs in the spring treatment, allowing shrub cover to increase relative to both the fall and exclosed treatments. The greater shrub cover in the spring paddocks may also have been facilitated by the improved microclimate for sagebrush seedling establishment found in the understory of older sagebrush plants (Wight et al. 1992). Because the differences in shrub cover among all 3 pooled treatments are likely a result of both direct herbivory and localized changes in plant competition, each merits further investigation.

The lower live shrub cover in the long-term fall treatment compared to the new fall treatment indicates that the increase in shrub cover via spring and fall grazing from 1924 to 1950 has not been fully ameliorated by fall-only grazing since 1950 . This suggests that overall reductions in shrub cover continue to reflect the amount of shrub present at the onset of fall grazing. Although average stocking rates within each type of grazing treatment were similar prior to and after 1950 (Table 1), the lower shrub cover may nevertheless be partly associated with the earlier intensity of sheep use. According to Mueggler (1950), the original treatments were occasionally used during the early years of the study as breeding pens and holding pastures. As a result, yearly fluctuations in stocking rates may have been very great, with unusually high years leading to greater shrub reductions, thus accounting for the differences in shrub cover among the 2 fall-grazed paddocks. Dead shrub cover parallelled that of live shrub cover, indicating that current attrition of shrubs may be relatively stable among treatments.

The differential cover of perennial and annual herb components among the grazing treatments suggests that independent tracking of these potential indicators may facilitate future monitoring within sagebrush steppe rangelands. Perennial forb cover was less abundant in the spring-grazed treatment. Significant yield reductions and increased mortality from spring or early summer defoliation have been documented for arrowleaf balsamroot (Blaisdell and Pechanec 1949), the dominant perennial forb. Spring grazing can also increase the mortality of bluebunch wheatgrass (Stoddart 1946), but the decrease in this species appeared to be offset by increases in other species that are more grazing tolerant, such as Sandberg bluegrass (Table 2). These results further support the conclusion of Mueggler (1950) and Laycock (1967) that spring 
grazing is detrimental to perennial herbs, especially the forb component. This conclusion though, may again underestimate the potential effect of shrub suppression on herb growth within the spring-grazed treatments. The level of competition and intensity of defoliation have both direct and interactive effects on herb growth (e.g., Mueggler 1972). Because the fall and exclosed treatments were similar in shrub cover, but dissimilar in live herb cover, changes in interspecific competition probably augment the effects of defoliation. The increased availability of resources for herbaceous growth following shrub suppression by fall grazing may be why Laycock (1967) concluded that continued fall grazing actually aids herb recovery compared to total livestock exclusion.

Incomplete recovery of perennial forb cover was evident in both the new fall-grazed paddock and the new exclosure, indicating that cessation of sheep grazing failed to facilitate recovery more than continued fall grazing. In contrast, perennial grass cover was similar among these treatments and therefore more resilient, perhaps due to the increased longevity of grasses when ungrazed during the growing season (e.g., bluebunch wheatgrass, see West et al. 1979). Perennial grasses may also have seed production characteristics and dispersal mechanisms that are more conducive to rapid establishment following a change in season of grazing. The uniform grass cover among treatments could also reflect the tendency of shrub crowns in the spring treatment to act as refugia for grasses. By comparison, forbs, which were observed more often in the interspaces between shrubs, may be more susceptible to repeated grazing. Although sagebrush understory may provide a favorable microclimate for herb seedling establishment (Wight et al. 1992), herb recovery was greater in the new fall-grazed paddock (with fewer shrubs) compared to the new exclosure. Thus, three-tip sagebrush primarily appears to be a competitor rather than a nurse plant for young herbs. Perennial grass and forb cover, and balsamroot density continue to be similar within the 2 spring-grazed paddocks. Thus, heavy spring grazing by sheep degrades these rangelands not only quickly (Laycock 1967), but perhaps, for a very long time.

Reduced balsamroot densities on these sites over the last 46 years could be a concern if this species is desired (e.g., for spring sheep grazing). However, because the reductions took place across all treatments, including the exclosures, these reductions do not appear to be related exclusively to sheep-grazing, and may represent natural stochasticity in balsamroot populations over time.

The annual grass and forb components had the opposite response to that of perennials (i.e., greater within spring treatments). Cheatgrass, the dominant annual, is a strong competitor because it continues to grow a root system in winter and monopolizes available moisture in spring (Harris 1967). Greater annual grass cover within spring-grazed areas may be caused by the reduction in competition associated with the decrease in perennial forb cover. The greater annual grass cover found on the long-term spring treatment compared to the new spring suggests that, similar to the discussion on shrub cover, the average documented stocking rates prior to 1950 (Table 1) may not accurately reflect the absolute maximum yearly use levels. A single year or 2 of unusually high stocking may have allowed for successful invasion of cheatgrass. Unexpectedly, annual forb cover was similar between the fall and spring treatments (Table 2). Although this may be attributed to the 'mass effect' (Hatton and Carpenter 1986) (i.e., fall treatments being surrounded by heavily grazed areas, thus promoting the seed-rain of annuals), this notion does not account for the low annual forb cover in the 2 relatively small exclosures. An alternative explanation is that soil crusts within all the grazed paddocks have been sufficiently disturbed, via trampling, to enable annual forbs to germinate and establish, regardless of the vegetation overstory composition (Mack and Thompson 1982). This change towards greater annual herb (and shrub) cover under previous spring grazing may represent a shift in the plant communities' herbaceous component over a competitive threshold and into a state where perennials can no longer thrive (Friedel 1991, Laycock 1991).

Cover values of soil surface-based components were relatively similar among treatments. This trend, particularly in exposed rock, suggests that surficial site differences were generally minimal among paddocks. Although lichen cover of soil is sensitive to grazing (Johansen 1984), lichen found within this study area had primarily colonized exposed basaltic rock outcrops, making them less susceptible to livestock disturbance. Moss cover was relatively greater in the exclosed treatments compared to the others. This may be due to either the favorable humidity and shaded conditions (Wight et al. 1992), which result from the more balanced overstory mixture of herbaceous and shrubby components within the exclosures, or to moss destruction via livestock trampling within the grazed paddocks.

The greater bare soil found within the fall treatment compared to the spring was unexpected. Because bare soil and live shrub cover were similar in fall-grazed and exclosed areas, the lower amount of bare soil within the spring paddocks may be due to the predominant shrub canopy. Abundant shrubs would provide both a direct protective overstory as well as leaf litter that is more recalcitrant (Comanor and Staffeldt 1978) than the herbaceous litter found within the other treatments. Nevertheless, these differences in bare soil merit further investigation and could indicate that the examination of vegetation components may be more important and practical for evaluating range condition on this study area than soil-based components. This notion is in contrast to the recommendations of the NRC (1994) that soil characteristics should be the first to be addressed during rangeland assessment procedures. As a result, monitoring efforts should continue to address both the vegetational and soil-based components of rangelands.

\section{Conclusions}

This study indicates that the long-term vegetational differences described by Mueggler (1950) and Laycock (1967) on the longterm fall and spring sheep-grazed study area, continue to persist. Spring sheep grazing of this three-tip sagebrush steppe rangeland has resulted in lower perennial herb cover and balsamroot densities, and more annual herb and sagebrush cover. In contrast, the fall-grazed paddocks had lcss sagebrush, more perennial herb, and only moderate annual herb cover. The three-tip sagebrush steppe ranges within the study area that were switched from spring and fall use to either fall or non-use continue to have less perennial herb cover than the original fall and exclosures, respectively. As a result, this study area appears to have relatively low resilience following prolonged spring sheep grazing, potentially an indication that spring grazing results in a change in competitiveness among growth forms and eventually, the establishment of a new steady state (Friedel 1991, Laycock 1991). However, 
this finding does not preclude the possibility that these areas are continuing to improve over the long-term, and may eventually recover completely. Although exclosure to sheep grazing resulted in more floristically-balanced plant communities, exclusion following heavy spring use resulted in less recovery of perennial herb cover compared to the spring and fall used range that continued to be grazed during the fall. This may indicate that fall grazing provides an active opportunity for management (Westoby et al. 1989) to facilitate greater recovery of perennial herb cover on sagebrush steppe rangeland.

This information has implications for the restoration of vegetationally altered three-tip sagebrush steppe rangelands: long-term management and monitoring strategies must be employed because sagebrush steppe responds slowly (in practical terms) to changes in the timing of sheep grazing. Furthermore, if alternate means of controlling shrub cover (e.g., periodic prescribed fire) are not employed on similar rangelands excluded from livestock use, shrub expansion and subsequent understory (i.e., herb) suppression is likely. A plausible alternative is to implement a grazing regime involving fall sheep grazing. The long-term pattern of degradation and recovery within this rangeland appears to be complex, non-linear over time (with recovery being slower than degradation), and dependent on the seasonality of grazing.

\section{Literature Cited}

Anonymous. 1993. Climatological Data Annual Summary -Idaho. NOAA Report, Vol. 96, \#13.

Archer, S. and F.E. Smeins. 1991. Ecosystem-level processes. pp. 109 139, In: R.K. Heidtschmidt and J.W. Stuth (eds), Grazing mangement: an ecological perspective. Timber Press Inc., Portland, Ore.

Belnap, J., K.T. Harper, and S.D. Warren. 1994. Surface disturbance of cryptobiotic soil crusts: nitrogenase activity, chlorophyll content, and chlorophyll degradation. Arid Soil Res. Rehab. 8:1-8.

Blaisdell, J.P. and J.F. Pechanec. 1949. Effects of herbage removal at various dates on vigor of bluebunch wheatgrass and arrowleaf balsamroot. Ecol. 30:298-305.

Blaisdell, J.P., R.B. Murray, and E.D. McArthur. 1982. Managing intermountain rangelands-sagebrush-grass ranges. USDA Forest Serv., Intermountain Res. Sta., Gen. Tech. Rep. 134.

Bork, E.W., N.E. West, J.A. Doolittle, and J. L. Boetling. (in press). Rangeland site assessment of grazing treatments using electromagnetic induction. J. Range Manage.

Comanor, P.L. and E.E. Staffeldt. 1978. Decomposition of plant litter in two western North American deserts. pp. 31-49, In: West, N.E. and J.J. Skujins (eds.), Nitrogen in desert ecoystems. Dowden, Hutchinson and Ross, Stroudsberg, Penn.

Craddock, G.W. and C.L. Forsling. 1938. The influence of climate and grazing on spring-fall sheep range in southern Idaho. USDA. Agr. Tech. Bull. 600 .

Floyd, D.A. and J.E. Anderson. 1982. A new point interception frame for estimating cover of vegetation. Vegetatio 50:185-186.

Floyd, D.A. and J.E. Anderson. 1987. A comparison of three methods for estimating plant cover. J. of Ecol. 75:221-228.

Friedel, M.H. 1991. Range condition assessment and the concept of thresholds: A viewpoint. J. Range Manage. 44:422-426.

Friedel, M.H., G.N. Bastin, and G.F. Griffin. 1988. Range assessment and monitoring in arid lands: the derivation of functional groups to simplify vegetation data. J. Environ. Manage. 27:85-97.

Harris, G.A. 1967. Some competitive relationships between Agropyron spicatum and Bromus tectorum. Ecol. Monogr. 37:106-111.

Hatton, T.J. and A.T. Carpenter. 1986. An empirical test of the mass effect determinant of species richness. Vegetatio 68:33-36.

Hurlbert, S.H. 1984. Pseudoreplication and the design of ecological field experiments. Ecol. Monogr. 54:187-211.
Johansen, J.R. 1984. Response of soil algae to a hundred-year storm in the Great Basin Desert, Utah. Phykos 23:51-54.

Kartesz, J.T. 1994. A synonymized checklist of vascular flora of the United States, Canada, and Greenland: Vol. 1 - checklist. 2nd ed. Timber Press, Portland, Ore

Laycock, W.A. 1963. An annotated bibliography of range management publications from the U.S. Sheep Experiment Station. Wyoming Range Manage., Issue No. 175.

Laycock, W.A. 1967. How heavy grazing and protection affect sagebrush-grass ranges. J. Range Manage. 20:206-213.

Laycock, W.A. 1991. Stable states and thresholds of range condition on North American rangelands: A viewpoint. J. Range Manage. 44:427-433.

Mack, R.N. and J.N. Thompson. 1982. Evolution in steppe with few large, hooved mammals. Amer. Nat. 119:757-773

Mueggler, W.F. 1950. Effects of spring and fall grazing by sheep on vegetation of the Upper Snake River Plains. J. Range Manage. 3:308-315.

Mueggler, W.F. 1972. Influence of competition on the response of bluebunch wheatgrass to clipping. J. Range Manage. 25:88-92.

National Research Council. 1994. Rangeland health: new methods to classify, inventory, and monitor rangelands. National Academy Press, Washington, D.C.

Natural Resource Conservation Service. 1995. Soil investigation of ARS United States Sheep Experiment Station headquarters range. USDA Nat. Res. Cons. Serv., Rexburg, Ida.

Pechanec, J.F. and G. Stewart. 1949. Grazing spring-fall sheep ranges of southern Idaho. USDA Circ. 808.

Stoddart, L.A. 1946. Some physical and chemical responses of Agropyron spicatum to herbage removal at various seasons. Utah Agr. Exp. Sta. Bull. 324.

West, N.E. 1983. Western intermountain sagebrush steppe. pp. 351-397. In: N.E. West (ed), Ecosystem of the World 5: Temperate deserts and semi-deserts. Elsevier Sci. Publ. Co., New York, N.Y.

West, N.E. 1990. Structure and function of microphytic soil crusts in wildland ecosystems of arid to semi-arid regions. Advances in Ecol. Res. 20:179-223.

West, N.E., K.H. Rea, and R.O. Harniss. 1979. Plant demographic studies in sagebrush-grass communities of southeastern Idaho. Ecol. 60:376-388.

Westoby, M., B. Walker, and I. Noy-Meir. 1989. Opportunistic management for rangelands not at equilibrium. J. Range Manage. 42:265-273.

Wight, J.R., F.B. Pierson, C.L. Hanson, and G.N. Flerchinger. 1992. Influence of sagebrush on the soil microclimate. pp. 181-185, In: Proceedings - Symposium on Ecology and Management of Riparian Shrub Communitics, USDA Forest Serv., Intermountain Res. Sta., Gen. Tech. Rep. 289.

Wright, H.A. 1970. Response of big sagebrush and three-tip sagebrush to season of clipping. J. Range Manage. 23:20-22. 